УДК 334. 021

Битов В.П., к.е.н., доцент

Bitov V. Candidate of Economic Sciences, Associate Professor https://orcid.org 0000-0002-5828-0143

Горбач Л.М., к.е.н., доцент

Horbach L. Candidate of Economic Sciences, Associate Professor https://orcid.org 0000-0002-5977-6474

Котляров В.О., к.е.н., доцент

Kotliarov V. Candidate of Economic Sciences Associate Professor https://orcid.org 0000-0002-2291-3199

\title{
ЕКОНОМІЧНІ МЕТОДИ УПРАВЛІННЯ ЯК ГОЛОВНІ ВАЖЕЛІ ЕФЕКТИВНОГО РОЗВИТКУ ПІДПРИЕМСТВА
}

\author{
Міжрегіональна Академія Управління Персоналом, Украӥна
}

\begin{abstract}
У науковій статті розглянуто роль, значення і дієвість надзвичайно важливого питання, а саме економічних методів управління, що посідають сьогодні найважливіше місце в системі методів менеджменту. Адже економічні методи в сучасному управлінні впливають як на ефективний розвиток суб'єктів господарювання так як охоплюють питання виробництва і реалізації виробленої ними продукції, ціноутворення, інвестування, кредитування, ведення чіткого госпрозрахунку, систему податків і інші економічні важелі.
\end{abstract}

Наші дослідження і практичний досвід показують, що економічні методи є особливо важливими i актуальними в період формування ринкових умов, які наділяють господарюючі підприємства самостійно формувати ціни на продукцію чи послуги, самостійно обирати поставщиків необхідних ресурсів, а також запроваджувати ту чи іншу форму оплати праці, як головного стимулу працівників підприємства та інше. Враховуючи це якраз широке та вміле використання економічних методів дає можливість уникнути небажаних прорахунків, а то й запобігти окремих ризиків в господарській діяльності.

Також нами в статті показано якраз те, що в умовах сьогодення без вмілого застосування економічних методів управління неможливо досягти бажаних результатів в діяльності того чи іншого підприємства, адже економічні методи управління охоплюють цілий комплекс взаємопов'язаних питань, без яких марно сподіватися на ефективні результати виробничої діяльності.

В статті відображено також роль економічних методів та їх взаємодоповнюючих складових, що прямо впливають на розвиток питань соціальної значимості колективу підприємства, що є в даний час надзвичайно важливим, адже дає можливість в забезпеченні дієвого та позитивно морального настрою працюючих на підприємстві.

Особливу увагу у публікації звернуто на виняткову важливість економічних методів управління, які є досить дієвими важелями у забезпечені ефективного госпрозрахунку підприємства, адже лише на розрахунковій основі по кожному напрямку господарської діяльності стає можливим забезпечити основне завдання господарюючого підприємства, а саме, досягти максимального прибутку 3 найменшими витратами.

В даній публікації досить змістовно показано як економічні методи управління сприяють виконанню певних взаємопов'язаних відповідних функцій менеджменту. Наведені окремі приклади досягнутих виробничих та фінансових здобутків, а також матеріального стимулювання працюючих в сільськогосподарських підприємствах Волинської області завдяки використанню ефективних методів управління.

Ключові слова: економічні методи управління, ціноутворення, планування, економічне стимулювання, інвестииії, прибуток, комериійний розрахунок, податкова політика.

\section{ECONOMIC MANAGEMENT METHODS AS THE MAIN LEVERS OF EFFECTIVE ENTERPRISE DEVELOPMENT}

\section{Interregional Academy of Personnel Management, Ukraine}

The scientific article considers the role, significance and effectiveness of an extremely important issue, namely economic management methods, which today occupy the most important place in the system of management methods. After all, economic methods in modern management affect the effective development of economic entities as they cover issues of production and sale of their products, pricing, investment, lending, selffinancing, tax system and other economic levers. 
Our research and practical experience show that economic methods are especially important and relevant in the period of market conditions, which give businesses to independently form prices for products or services, independently choose suppliers of necessary resources, as well as to introduce one or another form of remuneration. incentives for employees of the enterprise and more. Given this, it is precisely the wide and skillful use of economic methods that makes it possible to avoid unwanted miscalculations, and even to prevent certain risks in economic activity.

We also show in the article that in today's conditions without the skillful use of economic management methods it is impossible to achieve the desired results in the activities of an enterprise, because economic management methods cover a range of interrelated issues, without which it is useless to hope

The article also reflects the role of economic methods and their complementary components that directly affect the development of social significance of the enterprise, which is currently extremely important, because it allows to ensure effective and positive morale of employees.

The publication pays special attention to the exceptional importance of economic management methods, which are quite effective levers in ensuring effective self-sufficiency of the enterprise, because only on a settlement basis in each area of economic activity it becomes possible to ensure the main task of the economic enterprise. .

This publication shows in a very meaningful way how economic management methods contribute to the performance of certain interrelated relevant management functions. Some examples of achieved production and financial achievements, as well as material incentives for workers in agricultural enterprises of Volyn region through the use of effective management methods.

Key words: Economic management methods, pricing, planning, economic incentives, investments, profit, commercial calculation, tax policy.

Постановка проблеми у загальному вигляді та ії зв'язок 3 важливими науковими і практичними завданнями. Як свідчать наукові дослідження та практика господарської діяльності підприємств, на сьогодні економічні методи управління $\epsilon$ основними важелями, завдяки яким можливе досягнення ефективного розвитку підприємства, забезпечення його прибутковості і при цьому, що є особливо важливим, задоволення особистих інтересів кожного працівника підприємства через матеріальне стимулювання їх праці. 3 точки зору зв'язку економічних методів із науковими та практичними завданнями, слід відмітити, що насправді проглядається певний перелік їх збігу, або поєднання з окремими функціями управлінської діяльності i, зокрема, такими як планування, організація виробництва, ціноутворення, мотивація праці, контроль та регулювання, а також аналіз результатів господарської діяльності підприємства, що відображають вирішення практичних завдань їх діяльності.

Аналіз останніх досліджень і публікацій, у яких започатковано вирішення проблеми. Сутність і основний зміст методів управління полягає в поєднанні певних способів і прийомів впливу як на розвиток підприємства і його трудовий колектив, так i на конкретних працівників, що $\epsilon$ вагомою передумовою здійснення передбачуваних намірів результатів господарської діяльності. Як свідчать літературні джерела, та, спираючись на дослідження науковців, методи управління за змістом і відповідними функціями поділяються на економічні, організаційно-розпорядчі, соціальнопсихологічні, правові та технологічні, які між собою тісно взаємопов'язані.[7,с. 78].

Вивченню питань підвищення ефективності застосування економічних методів управління приділяли увагу багато вчених-економістів. Серед праць відомих ученихдослідників можна назвати основоположників управлінської науки: А.Маслоу, А.Файоля, М.Вебера, Г.Форда, а також сучасних науковців, які досліджують шляхи вирішення окреслених проблем управління, що спрямовані на ефективний розвиток господарюючих підприємств. Зокрема, цій проблемі присвячена низка наукових праць: Л. І.Козій, І.О.Слєпов, О.С.Вербова,А.І.Чуткий, Л.Л.Ковальська, І.М. Вахович та ін.

Однак, на нашу думку, в умовах сьогодення більшої уваги потребує вивчення як теоретичних засад, так і практичного застосування економічних методів управління, зокрема вдосконалення багатьох їх складових, а саме, ціноутворення, оплати праці, податкової політики, комерційного розрахунку, аналізу та контролю тощо. 
Все це свідчить про актуальність теми статті, яка зумовлена необхідністю теоретичного обгрунтування та практичного застосування економічних методів управління задля конкурентного розвитку підприємства.

Цілі статті. Мета статті полягає у розкритті сутності та ролі економічних методів управління, які цілеспрямовано впливають на створення належних умов для успішного розвитку підприємств та забезпечення прибутку. Зазвичай такі методи охоплюють питання планування господарської діяльності, госпрозрахунку, ціноутворення, кредитування, оподаткування та інші, що грунтуються на засадах ринкової економіки та спонукають господарюючі підприємства враховувати динаміку розвитку ринку та його кон'юнктуру. У даній публікації нами показано також вплив економічних методів управління, як головних важелів, що діють у сучасній економіці i, зокрема, на прикладах окремих сільськогосподарських підприємств Волинської області.

Виклад основного матеріалу. Важливість економічних методів управління, які $\epsilon$ досить дієвими важелями у забезпечені ефективного розвитку підприємства, полягає в тому, щоб забезпечити основне завдання господарюючого підприємства, а саме, досягти максимального прибутку з найменшими витратами.

В умовах сьогодення без вмілого застосування економічних методів управління неможливо досягти бажаних результатів у діяльності певного підприємства, адже економічні методи управління охоплюють комплекс питань, пов'язаних із стратегічним та поточним плануванням, формуванням цін, матеріальним стимулюванням працюючих, оподаткуванням тощо, без чого марно сподіватися на ефективні результати виробничої діяльності.

Як показують наші дослідження, питання планування у складових економічного методу є досить важливим, адже передбачає вивчення обсягів виробництва та ринку збуту виробленої продукції, потребу у залучені посередницьких структур із метою просування продукції до споживача, створення умов для залучення інвестицій та інше. Поряд 3 цим надзвичайно важливими в управлінській діяльності являються також вже нами названі такі економічні категорії як: ціна та ціноутворення, комерційний розрахунок, мотивація, а саме, оплата праці з їі формами та системами, кредитування, податкова політика, амортизація основних фондів. Також сюди належать такі важливі проблемні питання як економічне стимулювання i, відповідно, матеріальна відповідальність[1, с.64].

У цій статті ми зупинимося на розгляді окремих, на нашу думку, особливо важливих категоріях, які входять до складу економічних методів управління. Тому 3 цією метою наші дослідження були зосереджені на таких взаємодіючих складових економічних методів як: ціна і ціноутворення, податки, проблеми мотивації праці на підприємстві, а саме іiї оплати.

Щодо питання ціни, то на сьогодні це надзвичайно важлива економічна категорія, оскільки вона є індикатором якості продукції чи послуг, грошовим виразом вартості, але слід при цьому враховувати, що вартість, на відміну від ціни, $\epsilon$ розрахунковим, а не фактичним іiі значенням. Бо ціна $\epsilon$ категорією як вартісною (оскільки включає собівартість і прибуток), так і кон'юнктурною категорією, адже залежить від впливу ринку.

Ціна сьогодні по суті відображає діючу модель управління, оскільки виконує досить важливі функції, зокрема обліково-вимірювальну, розподільчу та стимулюючу, чим показує наскільки вміло застосовується управління економічними процесами, або ж наскільки невдало здійснюється управління економікою. Принагідно зауважимо, що в нинішніх умовах суб'єкти господарської діяльності самостійно встановлюють ціну, а саме формують основні іiі елементи, тобто до фактичної собівартості продукції чи послуг приєднують прибуток (Ц= C +П). При цьому варто відзначити, що приєднання до собівартості як до основного елементу ціни такого розрахункового прибутку, що 
забезпечує підприємству можливість успішно працювати і в основному за рахунок власних ресурсів. Таким чином, зауважимо, що ціна $\epsilon$ економічною категорією, складові елементи якої є основою для економічного розвитку підприємства [2, с.108].

Окреслимо механізм формування ціни, а саме ii складових на принципах економічного розрахунку, тобто ціни, якою користується кінцевий споживач продукції чи послуг[1, с.16]. До складових елементів ціни належать:собівартість, прибуток, непрямі податки (мито, акцизний збір. податок на додану вартість), а також приєднується за певних умов посередницько-збутова націнка і торговельна надбавка. Собівартість у складі ціни визначається підприємством на підставі обліку понесених витрат на вироблену підприємством продукцію чи надані послуги. Щодо прибутку у складі ціни, то він $є$ таким елементом, завдяки якому відбувається відшкодування понесених витрат, що пов'язані з виробництвом, а саме витрати на сировину, матеріали, оплату праці, амортизацію основних засобів, витрати на збут продукції та інше[3, с.57].

Слід зазначити, що такі елементи ціни, як собівартість i прибуток, $\epsilon$ обов'язковими, решта вищезазначених елементів не є обов'язковими. Такі елементи ціни можуть приєднуватися до ціни, або бути відсутніми залежно від соціальної значимості продукту, або ж від того,чи пов'язаний певний продукт із експортом або імпортом (де застосовується вид непрямого податку мито, що входить до складу ціни), а також чи підлягає певний продукт досить вагомому податку на додану вартість (де об'єктом оподаткування (ПДВ) є продаж продукції чи послуг суб' єктами господарської діяльності). Щодо вищезгаданого податку акцизного збору, то за цим видом податку оподаткуванню підлягають товари високорентабельної та монопольної продукції: тютюн, коштовності, алкогольні напої. [4, с.209].

Проблемним $є$ питання матеріального стимулювання працівників, а саме заробітна плата, яка поряд з іншими видами можливих доходів все-таки залишається основним мотивуючим стимулом працюючих людей.

П.Самуельсон у своїй відомій науковій праці говорить про важливість матеріального стимулювання, і головним при цьому визначається саме оплата праці. Вчений зазначає:«Не приходиться заперечувати той факт, що люди здають свої послуги в оренду, таку ціну їх послуг представляє тарифна ставка заробітної плати, яка посеред усіх інших товарних цін безумовно відіграє найважливішу роль i для більшості населення заробітна плата є єдиним доходом усієї сім'ї» [5, с.171]. В умовах сьогодення ринкові перетворення дають можливість людині мати ще й інші види доходів, скажімо від зайнятості підприємництвом, здачі в оренду майна, що знаходиться у приватній власності, доходи від пайової участі в сільськогосподарському виробництві та інше.

Однак, як свідчить практична дійсність, оплата праці є домінуючим джерелом доходів для більшості працездатного населення, а тому, на наше переконання, необхідно впроваджувати науково обгрунтовані та перевірені практикою перспективні форми та системи оплати праці. Адже вимоги нинішнього стану економіки держави та підприємств потребують додаткових нових виробничих потужностей, нових технологій, а значить, нових навиків, знань та кваліфікації працюючих. Праця буде продуктивною тоді, коли вона належно оцінюватиметься через матеріальне стимулювання.

На практиці у межах тарифної системи на підприємствах як виробничої, так і невиробничої сфери використовують різні форми оплати праці, зокрема, застосовуються дві іiі форми - погодинна і відрядна. Погодинна здійснюється відповідно до кількості затраченого (відпрацьованого) часу, а відрядна (поштучна) відповідно до кількості виробленої продукції чи виконаного обсягу робіт.

Основними умовами застосування певної форми заробітної плати є рівень технічної озброєності виробництва, характер технологічного процесу та організації 
виробництва і праці, ступінь використання виробничих потужностей і устаткування, обгрунтованість процесу нормування праці тощо.

При цьому зауважимо, що нині діючими системами відрядної оплати праці $\epsilon$ пряма відрядна, відрядно-преміальна, відрядно-прогресивна, непряма відрядна, акордна, колективна, або бригадна, а що стосується погодинної, то вона застосовується як: погодинна проста, погодинна преміальна, погодинна 3 нормованим завданням, а також за посадовими окладами[4,c.138]. Усі різновиди форм і систем оплати праці формуються на тарифній системі та нормуванні праці.

Проте, є специфічні умови застосування форм оплати праці. Наприклад, погодинна форма оплати праці застосовується за таки умов:

1) коли у робітника відсутня реальна можливість для збільшення випуску продукції. Це характерно для автоматичних ліній, конвеєрів i потокових ліній iз безперервним і чітко регламентованим режимом, для робіт на високомеханізованому устаткуванні й апаратурних процесах;

2) якщо результати праці робітника не можуть бути конкретно виміряні i кількісно виражені (налагодження верстатів, інструктаж тощо);

3) коли економічно недоцільно стимулювати зростання виробітку понаднормово, тобто коли перевиконання цих норм досягається через порушення технологічних режимів і погіршення якості робіт. До таких робіт відносять випробування продукції, термічну обробку і металопокриття виробів.

Для відрядної оплати праці необхідна наявність прямо пропорційної залежності між витратами живої праці й одержаними результатами, тобто працівник повинен вмотивовано збільшувати випуск продукції відповідно до потреб виробництва і ринку взагалі.

Проведені нами дослідження оплати праці на прикладах підприємств сільськогосподарського виробництва Волинської області свідчать, що на сьогодні найбільш поширеною є відрядна форма оплати праці, погодинна оплата праці зазвичай використовується для оплати технічних працівників, спеціалістів, інших працівників підприємства, де немає необхідності вести облік обсягу виконаних робіт. Варто зауважити, що практика застосування відрядної оплати застосовується і у більшості господарюючих підприємств України. Як зазначалося вище, відрядна форма оплати праці безпосередньо залежить від кількісних результатів, передбачає нарахування заробітної плати за кількість виробленої працівником продукції і використовується насамперед для оплати праці робітників на виробництві. При цьому, за кожну одиницю продукції встановлюється певний розмір оплати - відрядна розцінка.

Щодо практичного застосування відрядної оплати праці, то це відбувається на умовах обліку кількості виробленої продукції, або виконання певного обсягу роботи 3 передбаченою розрахунковою нормою часу і відповідної розцінки для виробленого певного продукту чи виконаної роботи, наприклад, виготовлено п'ятдесят стільців, прокладено тридцять метрів водопровідних труб та таке інше.

Як свідчить практика, саме така методика служить для правильного нарахування оплати праці і дозволяє визначити продуктивність праці за відомою розрахунковою нормою часу для заданого обсягу виробництва продукції чи виконання робіт i фактично затраченого часу за виконаний обсяг роботи, чи виробленої продукції[4,c.142].

Результати дослідження свідчать про те, що підприємства найчастіше використовують такі системи відрядної оплати праці як: відрядно-преміальна, відрядно-прогресивна, а також непряма відрядна, а при необхідності і погодинну форму оплати праці.

Щодо відрядно-преміальної форми оплати праці, то ï сутність полягає в тому, що працівнику, крім заробітку за прямою відрядною системою, нараховується премія за виконання (чи перевиконання) певних кількісних і якісних показників. Розмір премії 
встановлюється керівництвом за згодою профспілки, або передбаченого колективним договором між роботодавцем і працівниками підприємства у відсотках до тарифного заробітку, визначеного за відрядними розцінками. Відрядно-преміальна система оплати працінайбільше поширена і застосовується на практиці. Зокрема, вона передбачає, що робітник одержує не тільки заробіток за відрядною розцінкою, а й премію, яка встановлюється за виконання більших понад встановлених нормованих показників, а також при забезпеченні якісних показників за результатами своєї праці, економії матеріальних ресурсів та інше.

Відрядно-прогресивна оплата праці застосовується значно менше, а саме залежно від потреби виробничого процесу підприємства. Відрядно-прогресивна форма оплати праці передбачає оплату за вироблену продукцію в межах плану за прямою відрядною формою оплати праці за відрядними розцінками, а виконання роботи понад норму (за прогресивно зростаючими відрядними розцінками). Інакше кажучи, розцінки збільшуються прогресивно зі збільшенням кількості продукції, виробленої понаднормово. Така оплата праці може запроваджуватися на обмежені терміни в тих виробництвах, де потрібні додаткові заходи для стимулювання інтенсивності праці для досягнення прогресивних норм виробітку. При відрядно-прогресивній системі заробіток працівника підприємства визначається за фактичним виконанням норми виробітку (це подібно як при прямій відрядній), а щодо нарахування прогресивних доплат, то вони проводяться зазвичай за підсумками результатів роботи за місяць.

Під час підготовки статті, нами вивчався практичний досвід застосування економічних методів управління керівництвом та спеціалістами на відомому у Волинській області сільськогосподарському підприємстві «Пятидні» ВолодимирВолинського району. Це підприємство займається вирощуванням зернових, зернобобових, технічних та олійних культур на площі понад вісімнадцять тисяч гектарів, а також виробництвом насіння зернових культур, що готується на потужному високотехнологічному побудованому в господарстві насіннєвому заводі. На елеваторі цього заводу працює понад три десятки робітників, є також працівники, що працюють iз вантажними перевезеннями залізничним транспортом. Підприємство має власний тепловоз та понад 100 вагонів. На згаданому елеваторі обладнана і працює сучасна лабораторія, де визначаються всі необхідні показники посівного матеріалу і підготовленого для посіву насіння. За даними керівника господарства В.Г. Діброви, завдяки оснащеності найсучаснішою технікою, робота лабораторії проводиться швидко та якісно і приносить вагомі фінансові результати.

Основними культурами в господарстві є озима пшениця, ріпак, кукурудза, соя, цукровий буряк, горох та соняшник.У структурі посівних площ до $35 \%$ займає озима пшениця, оскільки, як стверджує керівник підприємства В. Г. Діброва, при будь-яких умовах та коливаннях ціни ця культура ніколи не була збитковою. Врожайність посівів озимої пшениці в господарстві на площі понад шість тисяч гектарів становила по 7,5т/га. Щодо інших культур, то досягти намічених показників урожаю через нестачу вологи навесні не вдалося. Так, врожайність сої склала близько 3 т/га, озимого ріпаку на площі понад три тисячі гектарів отримали по 3,5 т/га, гороху на площі 700 гектарів зібрали лише по 3 т/га, що значно менше запланованих, унаслідок погодних умов, які склалися весною 2020 року.

Не дивлячись на це, за прогнозами спеціалістів підприємства, ці культури будуть прибутковими, адже відповідають високоякісним показникам, що впливатиме на ціну їх реалізації.

Керівник даного підприємства В. Г. Діброва зауважив, що за підсумками роботи господарства 2020 року, воловий збір зернових, зернобобових та олійних культур у кількісному виразі становить понад 119 тисяч тонн, рентабельність, як показник окупності, складе понад 40 відсотків, а також додав, що хороші результати самі по собі 
не приходять, їх потрібно здобувати повсякденною працею всього персоналу підприємства.

На розглянутому підприємстві широко використовують економічні методи управління як у плані модернізації засобів виробництва, забезпеченні якісних показників виробничої діяльності, підвищенні продуктивності праці, так i ціноутворення на товарну продукцію, а також значна увага приділяється матеріальному стимулюванню працюючих, яких у господарстві налічується залежно від сезонної зайнятості понад п'ятсот осіб, де основним видом матеріальної зацікавленості кожного працівника є застосування ефективних форм оплати праці. Тут використовується як погодинна, так і відрядна системи оплати праці, при цьому дотримуються, щоб та чи інша форма плати відповідала кількості затраченої праці та іï результатів, а саме виробництва продукції в кількісному виразі, або робіт, що оплачується за кількістю відпрацьованого часу.

Висновки. В даній статті нами окреслено сутність і практичне значення економічних методів управління як особливо важливих важелів у забезпеченні ефективного розвитку підприємства. Продемонстровано, що такі методи за умов їх вмілого застосування дають можливість одержати бажані результати у господарській діяльності підприємства. Із переліку складових економічних методів відображено вплив на результати господарської діяльності цін і, зокрема, ціноутворення, податкової політики, а також проблеми матеріального стимулювання, а саме, оплати праці як основного стимулу працюючих. Наведені окремі приклади вмілого застосування таких методів управління, що застосовуються в сільськогосподарських підприємствах Волинської області. У підсумку відмітимо, що особливо в даний час економічні методи управління $\epsilon$ особливо доречними для досягнення ефективних результатів господарської діяльності.

\section{Список бібліографічного опису:}

1. Орищак Я. О. Основи економіки: Підручник. Тернопіль, 1998. 111 с.

2. Бирман Л. Экономика фирмы: Учебное пособие, М.: М/н ун-т бизн. и управл., 2001.

3. Бандурка О. М. Фінансова діяльність підприємства: Підручник. К.: Либідь, 1998. 312 с.

4.Загальна економіка: Підручник. За ред. І. Ф. Радіонової. Кам’янець-Подільський, 2002. 383 с.

5. Самуельсон П. Економіка: підручник. М.: НПО «Алгон 1992. 414 с.

6.Горкавий В.К., Герасименко Ю.С. Формування собівартості продукції та ефективності витрат в сільськогосподарських підприємствах: монографія. Харків, 2015. 239с.

7. Сидоренко О. І., Редько П. С. Менеджмент: ситуаційні вправи: навч. посіб.: програма поширення ситуаційного методу навчання. К.: Консорціум із удосконалення менеджмент-освіти в Україні, 2004. 465 с.

\section{References:}

1. Oryshchak Ya. O. Fundamentals of Economics: Textbook. Ternopil, 1998. 111 p.

2. Birman L. Economics of the firm: Textbook, M .: M / n un-t bizn. and management, 2001.

3. Bandurka OM Financial activity of the enterprise: Textbook. K .: Lybid, 1998. 312 p.

4. General Economics: Textbook. For order. IF Radionova. Kamyanets-Podilsky, 2002. 383 p.

5. Samuelson P. Economics: a textbook. M .: NPO «Algon 1992. 414

6 . Gorky VK, Gerasimenko YS Formation of production costs and cost efficiencies in agricultural enterprises: a monograph. Kharkiv, 2015. 239 p.

7. Sidorenko OI, Redko PS Management: situational exercises: textbook. manual: program for the dissemination of the situational method of learning. K .: Consortium for Improving Management Education in Ukraine, 2004. 465 p

Дата подання публікації 10.03.2021p. 